\title{
Molecular Marker Application in Capsicum spp: A Supplement to Conventional Plant Breeding
}

\author{
Bhaganna Haralayya ${ }^{1 *}$ and I.S. Asha ${ }^{2}$ \\ ${ }^{1}$ Department of Genetics and Plant Breeding, UAHS, Shivamogga-577225, India \\ ${ }^{2}$ Department of Genetics and Plant Breeding, UAS, GKVK, Bengaluru-560065, India \\ *Corresponding author
}

\section{A B S T R A C T}

\section{Keywords}

Capsicum, Marker, Diversity, Mapping, MAS.

Article Info

Accepted:

28 September 2017

Available Online:

10 November 2017
Chilli, is spice cum vegetable crop having various nutritious, medicinal and industrial application values in it. It consists of many species of which only five are cultivated. Among these, Capsicum annuum is widely cultivated across the world followed by Capsicum frutescens. Many of the biotic and abiotic stress also effect the crop production. Molecular markers usage in this crop has hasten the crop breeding programme to select diverse parental line, screening for biotic stress, transfer of recessive alleles, identifying and mapping, introgression of these beneficial genes and helps in marker assisted selection (MAS). Now most advanced next generation sequencing and genotyping technologies have also been generating more genomic resources which have to be used efficiently for crop improvement in future.

\section{Introduction}

Chilli or Capsicum, is spice cum vegetable crop, belongs to solanaceae family (Greenleaf, 1986). It is native to Central and South America (Pickersgill, 1997) and in $17^{\text {th }}$ century it was introduced to India by Portuguese traders. Chilli is diploid in nature with chromosome number $2 \mathrm{n}=24$, genome size is $2700 \mathrm{Mb}$ and total available genes are 30,701 (Solgenomics). It consists of several species, of which, only five species viz., Capsicum annuum, Capsicum frutescens, Capsicum pubescence, Capsicum chinense and Capsicum baccatum are cultivated in different parts of the world (Perry et al., 2007). Three complexes have been identified in the Capsicum genus as given in Figure
1 (Taranto et al., 2016). Chilli is often cross pollinated crop and frequency of crosspollination in the field can range from just $2 \%$ to as high as $90 \%$ (Pickersgill, 1997).

Chilli contains steam volatile oils, carotenoids, fatty oils, vitamins viz., A, C, E along with mineral elements like molybdenum, manganese, folate, potassium and thiamine etc. (Bosland and Votava, 2003). It has industrial application for paprika oleoresin, capsaicinoids and carotenoids along with non-food uses for defense, spiritual, ethnobotanical (Kumar et al., 2006). A large number of carotenoids provide high nutritional value and the color to chilli. The 
pungency is due alkaloid capsaicinoids, these are synthesized in the placental tissue localizaded inside of the fruits (Wahyuni et al., 2013). According to an estimate for 201617, in India, chillies were cultivated on 845,000 ha with a total production of 2.12 million $t$ of dry fruits (NHB, 2017).

Chilli production in India is constrained by biotic stresses like fungal diseases viz., damping off (Pythium aphanidermatum), anthracnose or fruit rot (Colletotrichum capsici), fusarium wilt (Fusarium solani), powdery mildew (Leveillula taurica); bacterial disease viz., bacterial wilt; viral diseases viz., chilli veinal mottle virus, leaf curl, murda complex, tospo virus; nematode like Root-knot nematode (Meloidogyne) and insect pests viz., gram pod borer (Helicoverpa armigera), tobacco caterpillar (Spodoptera litura), thrips (Scirtothrips dorsalis), aphids (Aphis gossypii and Myzus persicae), red spider mite (Tetranychus), broad/yellow mite (Polyphagotarsonemus latus).

\section{Genetic markers and its types}

A trait that is polymorphic, easily and reliably identified, and readily followed in segregating generations and indicates the genotype of the individuals that exhibit the trait is known as genetic marker. There are three types as mentioned below

\section{Visible/morphological markers}

Flower pigmentation, fruit shape etc these traits represents actual phenotype which is easily scorable by naked eye, simple, rapid, inexpensive and these assays not require sophisticated equipments.

Some of the limitations are, available in lesser number, scored on whole plants, require specific environment for expression and are developmental stage specific.

\section{Protein markers- isozymes}

Detected as electrophoretic variants of proteins. They also generated by small changes in the coding sequences of the concerned genes that alter the amino acid sequences of the concerned proteins using small amount of tissue either taken from seedling stage or from seeds and this analysis is easy. Major drawbacks are, it very with tissue and developmental stage along with environment.

DNA markers- A molecular marker is a DNA sequence that is readily detected

As constant landmarks in the genome and transmitted by the Mendelian laws of inheritance from one generation to the next and detected as differential mobility of fragments in a gel or by hybridization with specific probe. Maximum numbers of markers are available throughout the genome exhibit more polymorphism located in DNA at the level of nucleotide bases which is source of biological function these arise from DNA mutations such as point mutation, insertions or deletions or errors in replication of DNA (Paterson, 1996). These are independent of environment and developmental stage of crop.

Markers available are Restriction Fragment Length Polymorphisms (RFLPs), Random Amplified Polymorphic DNAs (RAPDs), Simple Sequence Repeats (SSRs), InterSimple Sequence Repeats (ISSRs), Amplified Fragment Length Polymorphisms (AFLPs) and Single Nucleotide Polymorphisms (SNPs). Some novel markers include Randomly amplified microsatellite polymorphisms (RAMPO), Expressed Sequence Tag Polymorphisms (ESTPs), Conserved Orthologue Set (COS) markers, Amplified Consensus Genetic Markers (ACGMs), Gene Specific Tags (GSTs), Resistance Gene Analogues (RGAs) and 
Exon Retrotransposon Amplification Polymorphism (ERAP) (Gupta and Rustgi, 2004). Targeting Fingerprinting Markers (TFMs) are Conserved DNA-Derived Polymorphism (CDDP), Cytochrome P450Based Analogues (PBA), Intron-Targeting Polymorphism (IT), Start Codon Targeted (SCoT) Polymorphisms, Sequence-Related Amplified Polymorphism (SRAP) and Targeted Region Amplified Polymorphism (TRAP), Conserved Region Amplification Polymorphism (CORAP), Some Mobile element-based molecular markers include: Inter-Retrotransposon Amplified Polymorphism (IRAP) and Retrotransposon Microsatellite Amplified polymorphism (REMAP) Retrotransposon Based Insertion Polymorphism (RBIP), Retrotransposon Based Sequence Specific Amplification Polymorphism (SSAP) as mentioned literature (Semagn et al., 2006; Kumar et al., 2009; Ismail et al., 2016). The effective marker has following criteria (Jiang, 2013)

High level of polymorphism (Clear distinct allelic features).

Even distribution across the whole genome.

Co-dominance inheritance (so that heterozygotes can be distinguished from homozygotes).

Single copy and no pleiotropic effect.

Low cost to use.

No detrimental effect on phenotype (Selectivity neutral).

Markers can be easily exchangeable between laboratories.

In Capsicum sp., most of the research workers isolated genomic DNA from young leaf tissue following the method of Doyle and Doyle (1990) with minor modifications.
Molecular markers in Capsicum sp. are mainly being used for the following purposes

\section{Germplasm characterization, conservation} and utilization

For efficient, effective conservation and utilization of genetic resources, identification and characterization of germplasm is an important step. Molecular markers assist in ex-situ germplasm preservation; to sampling, management and development of core collection there by making decisions on multiplication and maintenance of plant accessions to make them exploitable by plant breeders. Similarly for in-situ it aid in recognition of the most representative populations within the 'gene pool' of a landrace (Sergio and Barcaccia, 2005). It is a tool for precise germplasm identification and builds crop plant collection based on presence of valuable genes and traits and also powerful tool for removing duplicates and to establish core collection (Barcaccia, 2009).

rDNA (18S and 5S) specific probe and heterochromatic banding pattern used for characterize cultivars (Romero-da Cruz et al., 2017). SSR markers were designed for conserved coding regions of $C$. аппиит could be able to amplify region in $C$. pubescens. SSR and ISSR markers used to characterize the cultivar of $C$. annuum and $C$. pubescens sp (Ibarra-Torres et al., 2015).

Genetic diversity analysis, heterotic pools prediction, DNA fingerprinting and protection of varieties.

The choice of using marker technique in diversity analysis is due their capacity to detect genetic diversity at higher level of resolution (the DNA), speed and information obtained from small quantity of plant material. It has shown that molecular markers are important tools in characterizing 
estimating genetic variability within and between species and populations (Nayak et al., 2005).

Thul et al., 2012 conducted diversity analysis by using floral characteristics and the molecular markers (RAPD and ISSR) and revealed that $C$. annuum accessions formed a single cluster in the molecular analysis as maintaining their flower characteristic. $C$. chinense accessions shared flower features with the accessions of $C$. frutescens and were found to be closer at genotypic level. $C$. luteum was found to be rather closer to $C$. baccatum complex, both phenotypically and genetically. The accession of $C$. eximium presenting purple flowers falls apart from the groupings, this found to be helpful towards delineation of the species specificity.

Genetic diversity also investigated by RAPD primer (Makari et al., 2009). AFLP marker based diversity study conducted by Krishnamurthy et al., 2015 and this inquiry shown that high number of polymorphic bands suggests that AFLPs are efficiently discriminator and powerful marker for classification, finger printing and diversity analysis.

Toledo-Aguila et al., (2016) conducted characterization study with microsatellite marker and opined that all of this genetic diversity found in the native and wild chili populations of Mexico must be protected and conserved for future studies. Principal component and clustering done indicates collection from different geographic region of Mexico. So this diversity can be exploited by selection. Morphological and molecular markers (RAPD and ISSR) employed in selecting parents for production segreganting population. The molecular markers are valid tags for the investigation of genetic diversity in $C$. annuum germplasm (Rana et al., 2014). SSR markers used in diverse parent selection for further breeding process including hybridization through which limits narrowing of genetic base and also guides in stalking of desirable genes. (Hossain et al., 2014).

ISSR markers were also used in genetic variation experiment reported that $\mathrm{UBC} 841$, LOL12, and LOL10 could be very useful due to their polymorphism (Pena-Ortega et al., 2016). Diversity Arrays Technology or (DArT) along with next generation sequences to discover higher number of markers (Mongkolporn and Kethom, 2016). SNP markers identified by DArT sequencing were used to study origin of species in various places and Clustering (Silvar et al., 2016). Genotyping by sequencing (GBS) analysis generated SNP markers used in diversity analysis of C. annnuum (Taranto et al., 2016).

These molecular markers help in heterotic group or pool construction. A heterotic group is a set of genotypes displaying similar hybrid performance when crossed with individuals from another, genetically distinct germplasm group. It helps in broadening genetic base and limits the uniformity of genotypes. Krisnamurthy et al., 2013 revealed that intermediately divergent parents produced remarkable heterotic cross by using AFLP and morphological markers. Isozyme markers (Peroxidase (PO) and Polyphenol oxidase (PPO) isozymes) can also be used for variety registration (Kumar et al., 2014). DNA profiling by RAPD (Sanatombi et al., 2010; Prasasd et al., 2013), AFLP and ISSR (Gaikwad et al., 2013) may be a useful tool for cultivar identification as well as for variety protection.

\section{Taxa identification, phylogenetic relationship and identification of adulterants}

Phylogeny is the history of descent of a group of taxa such as species from their common 
ancestors including in a study on the basis of their relationships so groupings indicates the degree of genetic similarities and dissimilarities among them (Patwardhan et al., 2014).

By the phylogenetic research results using RAPD markers on $C$. chinense from different geographic regions it has shown that within C. chinense three clusters are possible (Moses and Umaharan, 2012). Based on molecular marker study using RAPD, it is revealed that Naga king chilli (Bhoot Jolokia in Assam) is possibly an interspecific hybrid of $C$. chinense and $C$. frutescens (Bosland and Baral, 2007). An allopolyploid cultivar 'Dalle Khursani' $(2 \mathrm{n}=4 \mathrm{x}=48)$ a $C$. annuum complex its genomic DNA analysis with 30 RAPD based molecular markers only two primers are reproducible revealed that $C$. annuum and one with $C$. frutescens and two with $C$. chinense indicating close affinity with $C$. annuum (Jha et al., 2017).

Attempting towards sequence analysis of the nuclear ribosomal DNA (nrDNA) Internal Transcribed Spacers (ITS) region (Figure 2), the phylogenetic relationship of Naga King Chili showed a clear grouping from $C$. chinense and $C$. frutescens (Kehie et al., 2016).

Dhanya and Sasikumar (2010) mentioned that PCR based markers has been used for adulterant detection in chilli powder of by using species specific primers (mainly RAPD and SCAR markers).

The mapping of genes/QTL for qualitative and quantitative traits and Marker assisted selection (MAS)

A genetic map is a schematic representation of genetic markers in the specific order, in which they are located in a chromosome along with the distances between them. In most of the cases, Haldane (1919) and Kosambi (1944) mapping functions helps for converting recombination frequency into genetic distance.

For constructing the genetic maps we require mapping population which means population that is suitable for linkage mapping of genetic markers. etc. various types of mapping populations are F2, F2-derived F3 (F2:3), backcross (BC), backcross inbred lines (BILs), doubled haploids (DHs), recombinant inbred lines (RILs), near-isogenic lines (NILs), chromosomal segment substitution lines (CSSLs), immortalized F2, advanced intercross lines, recurrent selection backcross (RSB) populations, and interconnected populations as given in the Figure 3 (Singh and Singh, 2015). Most commonly used populations are F2 (Prince, et al., 1993; Livingstone et al., 1999; Djian-Caporalino et al., 2001; Kang et al.,2001; Ben-Chaim et al., 2001; Arnedo-Andres, et al., 2002; Blum et al., 2003; Lee et al., 2009; Maharijaya et al., 2015; Venkatesh et al., 2015), DH (DjianCaporalino et al., 2001; Sugita et al., 2005; Minamiyama et al., 2006) and RIL (Ogundiwin et al., 2005; Barchi et al., 2007; Naegele et al., 2014; Yarnes et al., 2013).

Conventional plant breeding is supplemented with molecular breeding approaches including both, the transgenic crops and the markerassisted selection (MAS). The use of molecular markers that are tightly- linked to target loci as a substitute for or to assist phenotypic screening or selection is known as MAS. Markers helps in indirect selection of desired alleles in earlier stages of plant life and early in breeding line development, polygenic and showing low heritability which requires additional breeding cycles (selfing) and/or expressed late in development. Progeny testing can be bypassed if codominant marker systems are used to identify recessive alleles present in the desired 
genotype (Frey et al., 2004). Markers are really beneficial for introgression of genes from breeding lines or wild relatives, MABC, marker-assisted recurrent selection (MARS) and pyramiding of genes.

\section{Molecular marker application for biotic stress}

To develop cultivar with host-plant resistance, considered as an economically viable and eco-friendly approach to manage biotic stress. Conventional breeding has met with limited success due polygenic control of resistance traits, wide range of pathogen strains distributed in different environments, Complexity of host-pathogen interaction and wide variability pathogenicity. So MAS is an effective and reliable approach. Specific geographic region isolates of pathogenspecific QTL controlling resistance is critical to breed for a cultivar with durable resistance (Truong et al., 2012).

For mapping QTL's conferring to anthracnose resistance mapping population derived from C.annuum variety 'Bangchang' $\mathrm{X}$ C.chinense PBC 932, the QTL map with 214 SNPs and covered $824 \mathrm{cM}$. Another mapping population obtained from $C$. baccatum 'PBC80' $\mathrm{x}$ 'CA1316, the map having 403 SNPs and $1270 \mathrm{cM}$ coverage (Struss et al., 2016). Suwor et al., 2017 conducted research on anthracnose disease resistance lines selection by marker assisted selection in introgressed lines PR1 (derived from PBC 932) and PR2 (derived from PBC 80) crossed to susceptible parent (PS). Validation of SCAR-Indel and SSR-HpmsE032 markers on F2 of the three way population revealed that their individual ability to predict correctly the resistant genotype was 65per cent; together it was 77 per cent.

QTL Pc.5.1 confers major QTL effect for resistance to root rot in germplam (Lefebvre et al., 2013). For Phytopthora root rot, two types of resistance one is oligogenic which follow gene for gene hypothesis by doing experiment on RIL population (Sy et al., 2008) and another one polygenic as studied by using intraspecific (C. annuum) $\mathrm{DH}$ population (Lefebvre and Palloix, 1996). A Perennial accession has 4 main QTLs controlling resistance to $P$. capsici. To make rapid progress in introgression, a DH285 line (has 3QTL) derived from the cross Perennial $\mathrm{X}$ Yolo Wonder YW, having all the chromosomal regions to be transferred was used as donor parent and YW, a bell pepper line used as recipient. Three cycle of Backcrossing has carried along with screening of markers linked to resistance allele's presence and lastly for recipient genetic background and they identified additive and epistatic effect of QTLs (Thabuis et al., 2004). Xu et al., (2014) revealed that SRAPMe6/Em15 marker linked with Phytophthora blight resistance.

The $M e 7$ gene as a resistance gene localized on long arm of the chromosome P9 (other Me genes like Me1, Me3, Me4, Me7, Mech1, Mech2 are also located on chromosome 9). To fine map the $M e 7$ gene using F2 individuals with SNP markers developed by reference genome information were used, yet no closer marker has identified. Nearly 22 NB-LRR candidates were identified in the flanking region by using Ren-Seq analysis (Changkwian et al., 2016). The tightly linked markers 375A and 226B can be used in marker assisted selection (MAS) to develop RKN resistant lines (Toth et al., 2016).

Two closely linked markers to the powdery mildew resistance gene PMR1 were developed and this gene was located on chromosome 4. These markers can be used for fine mapping of gene (Jo et al., 2016). Bs3 gene mediates the perception of avrBs3expressing strain of Bacterial spot pathogen, 
PCR based co-dominant DNA marker PR-Bs3 which help in diagnosis of pepper line (Romer et al., 2010). This becomes a tool in MAS to resistance breeding of bacterial spot.

Gene pyramiding strategy and molecular markers along with biological assays can be effectively used to transfer multiple virus resistance genes to the sweet Charleston line Y-CAR (Ozkaynak et al., 2014).

Resistant CMV genes are recessive in nature and these resistance genes from C. annum French Perennial and C. frutescens (BG2814-
6) to commercial varieties (bell, jalapeno and Anaheim) transferred by backcross method and tried to map CMV resistance QTL by PCR based marker after RFLP and RAPD marker conversion. Morphological traits were also employed along with RAPD molecular markers to identify CMV tolerant BC3 individuals Plants were $99.9 \%$ more similar to their recurrent parent, by this breeder effort reduced to few backcrossing cycles and it also avoided progeny test in each backcross (Herison et al., 2012), to introgress recessive gene governed CMV tolerance (Herison et al., 2004).

Table.1 QTLs associated with important trait of interest in pepper

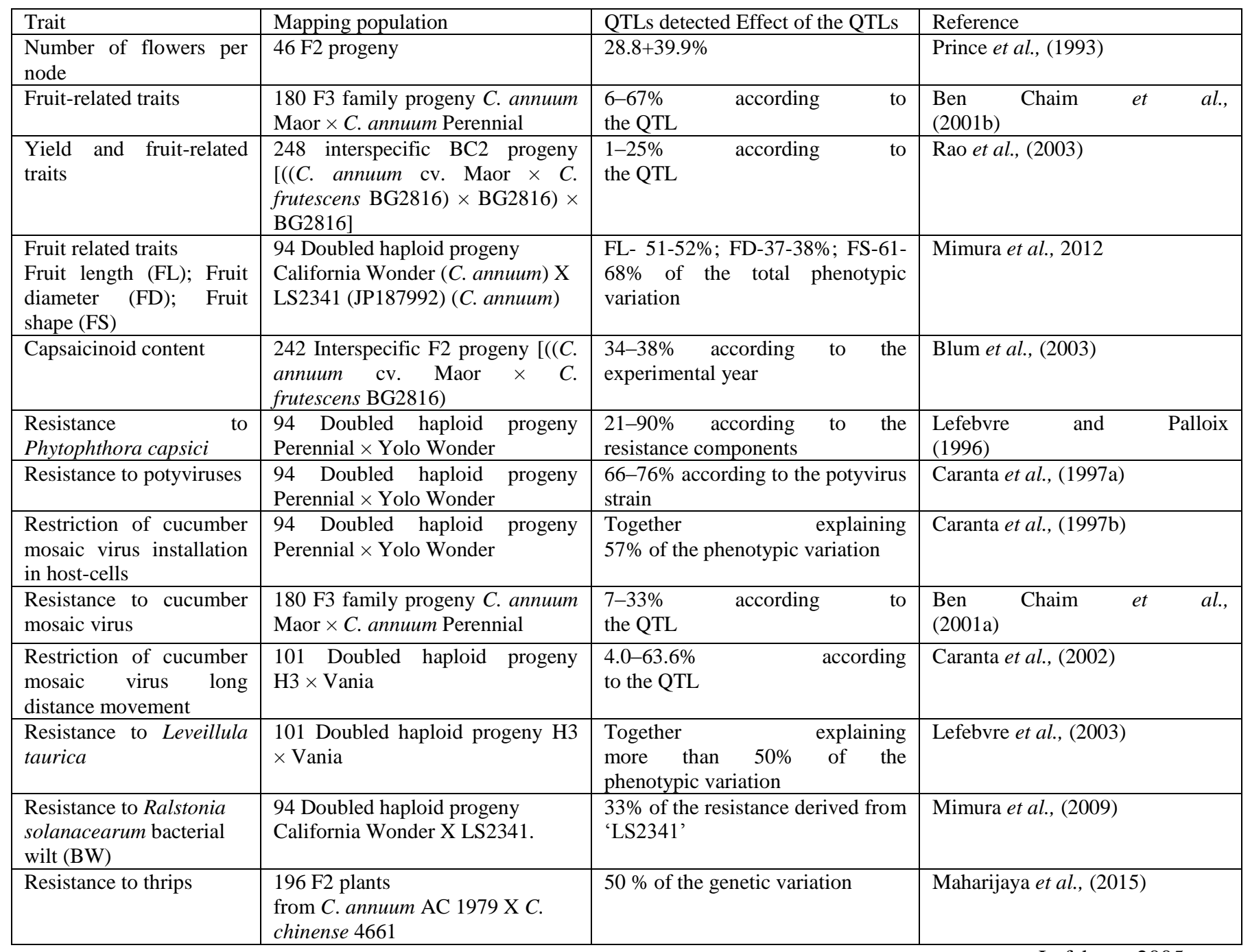


Fig.1 Main Capsicum complexes (the name of the complex is highlighted) (Taranto et al., 2016)

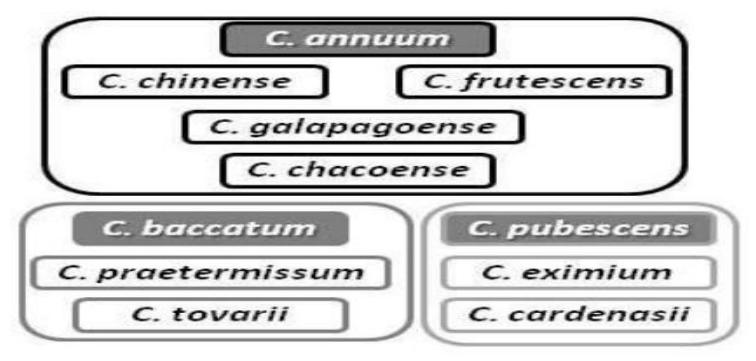

Fig.2 Organization of the eukaryotic nuclear ribosomal DNA tandem repeats [External

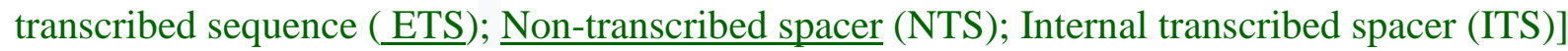

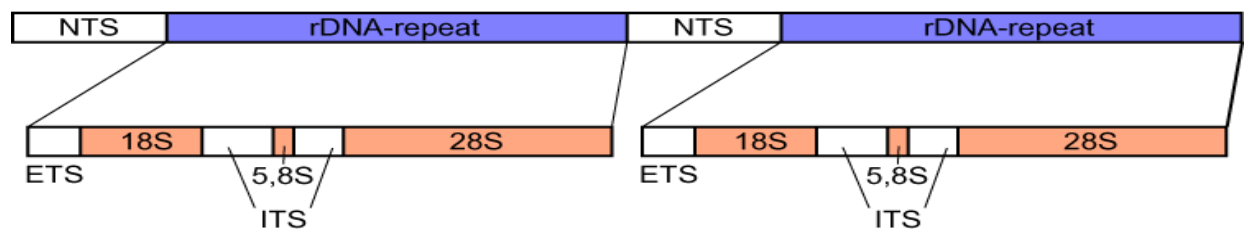

Fig.3 Simplified graphical chart of the various biparental mapping populations. ${ }^{*}$ Introgression of a gene by repeated backcrossing combined with selection for the gene. ** Repeated backcrossing without selection; each line has a distinct chromosome segment from the donor parent. (Singh and Singh, 2015)

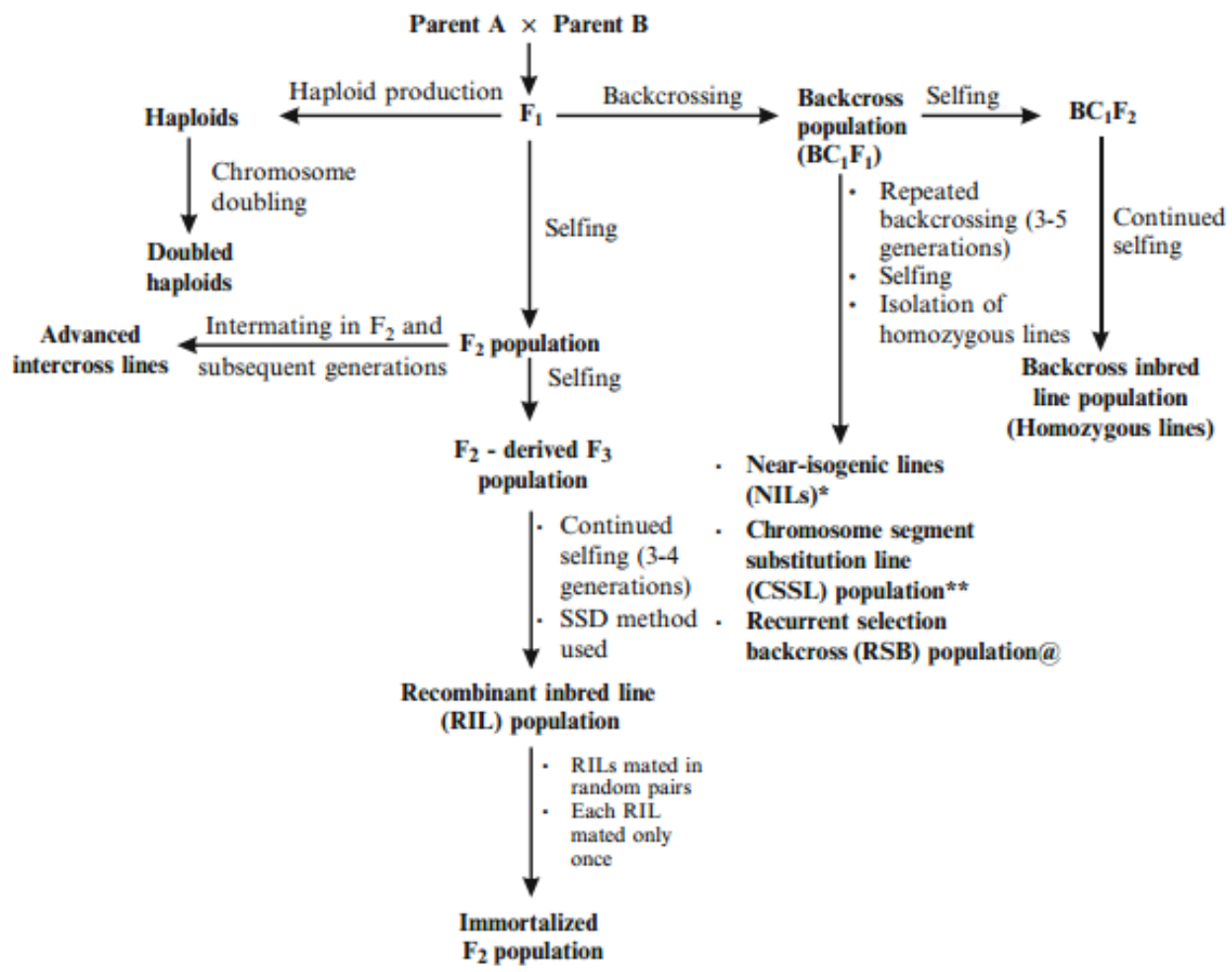


Basically Chilli veinal mosaic virus resistance is recessive in nature (Green and Kim 1994), but Indian landrace of $C$. annuum NW4 has dominant source of resistance gene. AFLP markers linked to this gene was converted into high-resolution melting markers for single nucleotide polymorphism (SNP) detection (chromosome 6) further CAPS marker obtained (Lee et al., 2013). Incorporation of the $T s w$ resistance gene from $C$. chinense was evaluated using the linked codominant SCAR T2 marker to Tsw. (Salamon et al., 2016). Pvr 4 loci confer dominant resistance to three pathotypes of PVY and PepMoV; markers linked to the resistance genes which were developed by next generation sequencing (NGS) technology along with BSA coupled with comparative genomics of pepper and tomato. Single nucleotide variants discovered were converted to CAPS markers. This helped in fine mapping of Pvr4 interval in pepper to $630 \mathrm{~kb}$ (Devran, 2015).

Pvr7 and Pvr4 is tightly linked dominant resistance genes, A CAPS marker linked to Pvr4 helped to localize this gene (Grube et al., 2000). RAPD marker converted to SCAR (SCUBC191423) linked to Pvr4 gene helps in MAS (Arnedo-Andres et al., 2002). Chilli veinal mottle virus (ChiVMV) resistance in 'IHR 2451' was monogenic recessive and K5HD6 a RGAP marker which co-segregated with ChiVMV resistance which helps in the marker assisted selection (Naresh et al., 2016). QTL associated with some important trait is given in Table 1.

According various researchers most of the genes for viral pathogens are present in the $C$. chinense L. PI159236. Majority of viral disease research is taken up in tomato and potato, by comparative maps explains conservation of marker content and also facilitates transfer of information between Solanaceae family (Livingstone et al., 1999).
As virus screening methods were laborious and expensive. These obstacles can be overcome by usage of MAS.

\section{Abiotic Stress}

Cross between popular high yielding, heat sensitive malaysian chilli variety Kulai and heat tolerant AVPP0702 done to introgress heat shock protein $(H s p)$ genes by following backcross method along with 252 SSR marker assisted selection to overcome linkage drag and time consumption problem of traditional breeding method. Recipient allele recovered to maximum of $83.40 \%$ in one of the $\mathrm{BC} 1 \mathrm{~F} 1$ plant (BC1P7) and was positive to $H s p$-linked markers (Hsp70-u2 and AGI42). Genome recovery of the recurrent parent after three successive generation of backcrossing was upto $95.37 \%$ (Usman et al., 2017).

\section{Quality}

From C. baccatum species for agronomically important traits 61 QTLs identified on 9 linkage groups (Moulin et al., 2015). Segregating doubled haploid progenies with RFLP and RAPD markers intraspecific integrated linkage map were constructed to locate $\mathrm{L}$ (hypersensitive resistance to TMV), $\mathrm{C}$ (fruit pungency), up (erect habit of the fruits) genes on chromosomes (Lefebvre et al., 1995). C. chinense is high pungent one (Tanaka et al., 2016). RFLP marker converted to CAPS markers. These markers also help in recessive c gene selection (Blum et al., 2002).

Markers help in handling large population of pepper for developing new low-pungent capsinoid containing cultivars development (Tanaka et al., 2014). Babak et al., 2016 developed STS marker particularly fruit quality gene i.e., analogue of the rin (ripening inhibitor) mutation specific to capsicum after comparative analysis of marker allele fragment sequence with tomato. 


\section{Male sterility}

Chilli male sterility has been reported by Peterson (1958). Inability of flowering plant to produce functional pollen grain is referred as male sterility. In majority of the crops male sterility is exploited for hybrid seed production (heterosis breeding) by preventing self-pollination. In chilli CMS, GMS and CGMS types are applicable. Markers mainly used to identify tight association with trait of interest, Possible to convert diverse lines into restorers and Maintenance of fertility restorer trait. S-cytoplasm (Kim and Kim, 2005) and the restorer-of-fertility $R f$ gene (Gulyas et al., 2006) are associated with molecular markers. For selection restorer and maintainer plants more widely distributed $R f$ gene which are tightly linked to markers would be required to exercise marker assisted selection (MAS) (Kumar et al., 2004). It permits classification of lines as either B or R without need for test crosses. For Restorer-of-fertility $(R f)$ based expression CaPPR6 (pentatricopeptide repeat protein) was identified as candidate gene by using BSA-AFLP and comparative mapping fine mapping and Co1Mod1-CAPS, which is located near CaPPR6 could be remarkable in MAS (Jo et al., 2016).

GMS is two lines breeding transferred among parental lines, in this most of the breeding lines are restorers, and no negative cytoplasmic effect (Mandaliya and Thaker, 2016). So GMS type of hybrid seed production was followed due to ease in introgression of genetically controlled recessive male sterility genes by backcross method where selfing is done after every backcross. In this case homozygous $(M s M s)$ and heterozygous (Msms) genotype identification was difficult, this was resolved by developing marker which is associated with control of male sterility in paprika by following Bulk segregant analysis in $\mathrm{F}_{2}$ population by making bulk of male sterile and male fertile and amplified fragment length polymorphism (AFLP), a dominant marker. Markers Egat/Mcgg (AFLP) was converted into PmsM1-CAPS (cleavage amplified polymorphic sequence) marker is located about 2 to $3 \mathrm{cM}$ from the $m s$ locus (Lee et al., 2010). Lee et al., (2010) reported that EAGC/M-GTG AFLP marker converted into co-dominant sequence characterized amplified region (SCAR) marker based on sequence information for $\mathrm{ms}_{1}$ locus selection located about $3 \mathrm{cM}$ distant from SCAR, which helps in GMS system. These codominant markers help in heterozygote selection without progeny test.

Detection of polymorphism, environmental interaction with genotype, time required for detection of recessive alleles are some of the constraints in conventional plant breeding strategies. Rapid, early detection of traits, screening of difficult traits and efficient molecular marker approaches hasten the crop improvement programme and also helps to breed for durable biotic stress tolerant ecofriendly cultivars with respect to major pepper diseases. MAS acts as complemtary tool for traditional plant breeding. Linkage and QTL mapping for various traits are providing an additional genomic resource to the plant breeders to speed up new cultivar development in future.

\section{References}

Arnedo-Andres, M.S., Gil-Ortega, R., LuisArteaga, M. and Hormaza, J.I. 2002. Development of RAPD and SCAR markers linked to the Pvr4 locus for resistance to PVY in pepper (Capsicum annuum L.). Theor. Appl. Genet., 105: 1067-1074.

Babak, O. G., Nikitinskaya, T. V., Yatsevich, K. K., Nekrashevich, N. A. AND Kilchevsky, A.V., 2016. Development of DNA-markers to fruit quality genes of sweet pepper (Capsicum annuum L.). Proceed. XVI ${ }^{\text {th }}$ Eucarpia, 137-144.

Barcaccia. G. 2009. Molecular markers for 
characterizing and conserving crop plant germplasm. In: Jain S., Brar D. (Ed.), Molecular Techniques in Crop Improvement. Springer, Dordrecht. pp 231254.

Barchi, L., Bonnet, J., Boudet, C., Signoret, P., Nagy, I., Lanteri, S., Palloix, A. and Lefebvre, V. 2007. A high-resolution, intraspecifi c linkage map of pepper (Capsicum annuum L.) and selection of reduced recombinant inbred line subsets for fast mapping. Genome. 50: 51-60.

Ben Chaim, A., Grube, R.C., Lapidot, M., Jahn, M. and Paran, I. 2001a. Identification of quantitative trait loci associated with resistance to cucumber mosaic virus in Capsicum annuum. Theor. Appl. Genet. 102:1213-1220.

Ben Chaim, A., Paran, I., Grube, R.C., Jahn, M., Wijk, V. R. and Peleman, J. 2001b. QTL mapping of fruit related traits in pepper (Capsicum annuum). Theor. Appl. Genet., 102:1016-1028.

Blum, E., Mazourek, M., O’Connell, M., Curry, J., Thorup, T., Liu, K., Jahn, M. and Paran, I., 2003. Molecular mapping of capsaicinoid biosynthesis genes and quantitative trait loci analysis for capsaicinoid content in Capsicum. Theor. Appl. Genet. 108:79-86.

Blum, E., Liu, K., Mazourek, M., Yoo, E.Y., Jahn, M. and Paran, I. 2002. Molecular mapping of the $\mathrm{C}$ locus for presence of pungency in Capsicum. Genome. 45(4): 702-705.

Bosland, P. W. and Votava, E.J. 2003. Peppers: Vegetable and Spice Capsicums. CAB International, England, p.333.

Bosland, P.W. and Baral, J. B. 2007. 'Bhut Jolokia' - the world's hottest known chile pepper is a putative naturally occurring inter-specific hybrid. Hort. Sci., 42 (2): 222-224.

Caranta, C., Lefebvre, V. and Palloix, A. 1997a. Polygenic resistance of pepper to potyviruses consists of a combination of isolate-specific and broad-spectrum quantitative trait loci. Mol Plant Microbe Interact. 10:872-878.

Caranta, C., Palloix, A., Lefebvre, V. and Daubeze, A.M. 1997b.QTLs for a component of partial resistance to cucumber mosaic virus in pepper: restriction of virus installation in host-cells. Theor. Appl. Genet. 94:431-438.

Caranta, C., Pflieger, S., Lefebvre, V., Daubeze, A.M., Thabuis, A. and Palloix, A. 2002. QTLs involved in the restriction of cucumber mosaic virus (CMV) longdistance movement in pepper. Theor. Appl. Genet., 104:586-591.

Changkwian, A., Han,J., Lee,J., Choi, G.and Kan, B. C. 2016. Fine mapping of the Me7 gene controlling resistance to Root-Knot Nematode (Meloidogyne incognita) in chili pepper. Proceed. XVI ${ }^{\text {th }}$ Eucarpia, 552.

Devran, Z.B., Kahveci, E., zkaynak, E.O., Studholme, D. J. AND Tor, M., 2015. Development of molecular markers tightly linked to Pvr4 gene in pepper using nextgeneration sequencing. Molecular Breeding. 35:101. DOI 10.1007/s11032015-0294-5.

Dhanya, K. and Sasikumar, B. 2010. Molecular marker based adulteration detection in traded food and agricultural commodities of plant origin with special reference to spices. Current Trends in Biotechnology and Pharmacy. 4(1): 454-489.

Djian-Caporalino, C., Pijarowski, L., Fazari, A., Samson, M., Gaveau, L., O'Byrne, C., Lefebvre, V., Caranta, C., Palloix, A. and Abad, P. 2001. High-resolution genetic mapping of the pepper (Capsicum annuum L.) resistance loci $\mathrm{Me} 3$ and $\mathrm{Me} 4$ conferring heat-stable resistance to root-knot nematodes (Meloidogyne spp.) Theor. Appl. Genet. 103:592-600.

Doyle, J. J. and Doyle, J. L. 1990. Isolation of plant DNA from fresh tissue. Focus. 12: 13-15

Frey, J. E., Frey, B., Sauer, C. and Kellerhals, M., 2004. Efficient low-cost DNA extraction and multiplex fluorescent PCR method for marker-assisted selection in breeding. Plant Breeding. 123:554-557

Gaikwad, A.B., Archak, S. and Gautam, D. 2013. DNA profiling of Capsicum annum L. cultivars based on AFLP and ISSR markers. Gene conserve: 12(49) - 4:12.

Green, S.K. and Kim, J.S. 1994. Sources of resistance to viruses of pepper (Capsicum 
spp.): a catalog Asian Vegetable Research and Development Center. Tech Bull 20:72.

Greenleaf, W. H. 1986. Pepper breeding. In: Basset, M.J. (Ed.), Breeding vegetable crops. The AVI Publishing Company Inc. Westport, Connecticut. pp. 67-134.

Grube, R.C., Blauth, J.R., Arnedo, M.S., Caranta, A.C. and Jahn, M.K. 2000. Identification and comparative mapping of a dominant potyvirus resistance gene cluster in Capsicum. Theor Appl Genet. 101:852859.

Gulyas, G., Pakozdik, K., Lee, J.S., Hirata, Y., 2006. Analysis of fertility restoration by using cytoplasmic male-sterile red pepper (Capsicum annuum 1.) lines. Breed. Sci. 56, 331-334

Gupta, P. K. and Rustgi, S. 2004. Molecular markers from the transcribed/expressed region of the genome in higher plants. Funct Integr Genomics.4: 139-162

Herison, C., Rustikawat and Sudarsono, 2004. Genetic nature of resistance against Cucumber Mosaic Virus in hot pepper. Capsicum and Eggplant News L. 23:111114.

Herison, C., Winarsih, S., Handayaningsih, M. and Rustikawati, 2012. DNA marker assisted and morphological selection on bc3 genotypes shortcut the introgression of CMV tolerance genes on chili pepper. Agrivita.34(3):215-224. http://dx.doi.org/10.17503/Agrivita-201234-3-p215-224

Hossain, S.M., Habiba, U., Bhuyan, S. I., Haque, M. S., Begum, S. N. and Hossain, D.M., 2014.Dna finger printing and genetic diversity analysis of chilli germplasm using microsatellite markers. Biotechnology 13(4): 174-180.

https://solgenomics.net/

Ibarra-Torres, P., Valadez-Moctezuma, E., PérezGrajales, M., Rodríguez-Campos, J. and Jaramillo-Flores, M.E., 2015. Inter- and intraspecific differentiation of Capsicum annuum and Capsicum pubescens using ISSR and SSR markers. Scientia Horticulturae 181: 137-146.

Ismail, N.A., Rafii, M. Y., Mahmud, T. M. M., Hanafi, M. M. and Miah, G. 2016. Molecular markers: a potential resource for ginger genetic diversity studies. Molecular Biology Reports. 43(12):1347-1358.

Jha, T.B., Saha, P.S., Nath,S., Das, A. and Jha, S. 2017. Morphological and cytogenetical characterization of Dalle Khursani: a polyploid cultivated Capsicum of India. Scientia Horticulturae 215:80-90

Jiang, G. 2013. Molecular markers and markers assisted breeding in plants. In: Sven Bode Andersen (Ed.), Plant breeding from laboratories to fields. DOI:10.5772/52583.

Jo, J., Kang, W., JaChoi, G., Kwon, J. and Kang, B., 2016 Genetic mapping of the Powdery Mildew Resistance (PMRI) gene in pepper (Capsicum annuum L.). Proceed. XVI ${ }^{\text {th }}$ Eucarpia,533.

Jo, Y.D., Ha, Y., Lee, J.H., Park, M.,Bergsma, A.C., Choi, H.I., Goritschnig, S., Kloosterman, B., Van Dijk, P.J., Choi, D. and Kang, B.C. 2016. Fine mapping of Restorer-of-fertility in pepper (Capsicum annuum L.) identified a candidate gene encoding a pentatricopeptide repeat (PPR)containing protein. Theor. Appl. Genet. 129 (10):2003-17.

Kang, B., Nahm, S.H., Huh, J.H., Yoo, H.S., Yu, J.W., Lee, M.H. and Kim, B.D., 2001. An interspecific (Capsicum annuum $\mathrm{x} C$. chinense) F2 linkage map in pepper using RFLP and AFLP markers. Theor. Appl. Genet. 102: 531-539.

Kehie, M., Kumaria, S., Devi, S.K. and Tandon, P. 2016. Genetic diversity and molecular evolution of Naga King Chili inferred from internal transcribed spacer sequence of nuclear ribosomal DNA. Meta Gene 7: 5663.

Kim, D.H. and Kim, B.D. 2005. Development of SCAR markers for early identification of cytoplasmic male sterility genotype in chili pepper (Capsicum annuum L.). Mol Cells. 20:416-422.

Krishnamurthy, S. L., Mohan Rao, A., Madhavi Reddy, K., Ramesh, S., Hittalmani, S. and Rao, G. R. 2013. Limits of parental divergence for the occurrence of heterosis through morphological and AFLP marker in chilli (Capsicum annuum L.). Current Science. 104(6): 738-746.

Krishnamurthy, S.L., Prashanth, Y., Rao, A.M.,Reddy, K.M. and Ramachandra, R., 
2015, assessmet of AFLP marker based genetic diversity in chilli (Capsicum annuum L. and C. baccatum L.). Indian J. biotech. 14:49-54

Kumar, O. A., Tata, S.S. and Rupavathi, T., 2014. Evaluation of genetic diversity in 21 cultivars of chili pepper (Capsicum annuum L.) using isozyme markers. European J. Experimental Biol., 4(6):44-49.

Kumar, P., Gupta, V.K., Misra, A.K., Modi, D.R. and Pandey, B.K. 2009. Potential of Molecular Markers in Plant Biotechnology. Plant Omics Journal. 2:141-162.

Kumar, S., Kumar, R. and Singh, J. 2006. Cayenne/American pepper. In: Peter, K.V. (ed.), Handbook of Herbs and Spices, Woodhead Publishing, Cambridge, UK. pp. 299-312.

Kumar, S., Singh, V., Singh, M., Kumar, S., Kalloo, G. and Rai, M., 2004. Testing validity of fertility restorer $(R f)$ gene associated RAPD markers in newly identified restorer and maintainer lines of pepper (Capsicum annuum L.). $\quad 4^{\text {th }}$ International Crop Sci. Congress.

Lee, H.R., An, H J., You, Y.G., Lee, J., Kim, H.J., Kang, B.C. and Harn, C. H. 2013. Development of a novel codominant molecular marker for chili veinal mottle virus resistance in Capsicum aпnиum $\mathrm{L}$. Euphytica (2013) 193:197-205.

Lee, H.R., Bae, I.H., Park, S.W., Kim, H.J., Min, W.K., Han, J.H., Kim, K.T. and Kim, B.D. 2009. Construction of an integrated pepper map using RFLP, SSR, CAPS, AFLP, WRKY, rRAMP and BAC end sequences. Molecules and Cells. 27: 21-37.

Lee, J., Yoon, J. B., Han, J.H.,. Lee., W.P., Do, J.W., Ryu, H.S., Kim, H., and Park, H. G. 2010. A codominant SCAR marker linked to the genic male sterility gene $(m s l)$ in chili pepper (Capsicum annuum). Plant Breeding. 129: 35-38.

Lefebvre, V. 2005. Molecular Markers for Genetics and Breeding: Development and Use in Pepper (Capsicum spp.). In: Lorz, H. and Wenzel, G. (Ed.), Biotechnology in Agriculture and Forestry 55. Molecular marker systems in plant breeding and crop improvement. Springer-Verlag Berlin Heidelberg. pp 189-210.
Lefebvre, V. and Palloix,A. 1996. Both epistatic and additive effects of QTL are involved in polygenic induced resistance to disease: a case study, the interaction pepper Phytophthora capsici Leonian. Theoretical and Applied Genetics 93, 503-11.

Lefebvre, V., Cantet, M., Vandecasteele, C., Vautrin, S., Bouchet, J.P., Massire, A.I., Bachellez, A.I., Touhami, N.I., Mallard, S.I., Le Paslier, M.C., Sage-Palloix, A.M.I., Bendahmane, A., Palloix A.I., Btrges, H. and Brunei. 2013. Analysis of a complex QTL region controlling the broad-spectrum resistance to Phytophthora capsici root rot by comparative mapping and association study in pepper germplasm Torino, 2-4 September 2013 XV EUCARPIA Meeting on Genetics and Breeding of Capsicum and Eggplant.

Lefebvre, V., Cantet, M., Vandecasteele, C., Vautrin, S., Bouchet, J.P., Massire A., Bachellez, A., Touhami, N., Mallard, S., Le Paslier M.C., Sage-Palloix A.M., Bendahmane A., Palloix A., Bergès, H. and Brunel, D. 2013. Analysis of a complex QTL region controlling the broad-spectrum resistance to Phytophthora capsici root rot by comparative mapping and association study in pepper germplasm. XV EUCARPIA Meeting on Genetics and Breeding of Capsicum and Eggplant.139146.

Lefebvre, V., Daubeze, A.M., Voort, R.V.J., Peleman, J., Bardin, M. and Palloix, A. 2003.QTLs

for resistance to powdery mildew in pepper under natural and artificial infections. Theor.Appl. Genet. 107:661-666.

Lefebvre, V., Palloix, A., Caranta, C. and Pochard, E., 1995. Construction of intraspecific integrated linkage map of pepper using molecular markers and doubled haploid progenies. Genome, 38(1): 112121.

Livingstone, K.D., Lackney, V.K., Blauth, J.R., Wijk, V.R. and Jahn, M.K.1999. Genome mapping in Capsicum and the evolution of genome structure in the Solanaceae. Genetics. 152:1183-1202.

Livingstone, K.D., Lackney, V.K., Blauth, J.R., Wijk, V.R. and Jahn, M.K.1999. Genome 
mapping in Capsicum and the evolution of genome structure in the Solanaceae. Genetics. 152:1183-1202.

Maharijaya, A., Vosman, B., Steenhuis- Broers, G., Pelgrom,K., Purwito, A., Visser, R.GF. and Voorrips, R. E. 2015. QTL mapping of thrips resistance in pepper. Theor Appl Genet 128:1945-1956.

Maharijaya, A., Vosman, B., Steenhuis- Broers, G., Pelgrom,K., Purwito, A., Visser, R.GF. and Voorrips, R. E. 2015. QTL mapping of thrips resistance in pepper. Theor Appl Genet 128:1945-1956.

Makari, H. K. Ravikumar Patil, H. S., Abhilash, M. and Mohan Kumar H. D. 2009. Genetic diversity in commercial varieties of chilli as revealed by RAPD method. Indian J. Sci.Technol., 2 (4): 91-94.

Mandaliya, V.B. and Thaker, V.S. 2016. Molecular markers in Male Sterility: Step Towards Crop Improvement. International J. Molecular Biol. Biochem., 4 (1): 1-12.

Mimura, Y., Inoue, T., Minamiyama, Y. and Kubo, N., 2012. An SSR-based genetic map of pepper (Capsicum annuum L.) serves as an anchor for the alignment of major pepper maps. Breeding Science. 62: 93-98.

Mimura,Y., Kageyama, T., Minamiyama, Y. and Hirai, M. 2009. QTL Analysis for resistance to Ralstonia solanacearum in Capsicum accession LS2341. J. Japan. Soc. Hort. Sci. 78 (3): 307-313.

Minamiyama, Y., Tsuro, M. and Hirai, 2006. An SSR-based linkage map of Capsicum annuum. Mol Breeding. 18: 157-169.

Mongkolporn, O.and Kethom, W. 2016. Genetic diversity of Thai native chili using diversity arrays technology. Proceed. XVI ${ }^{\text {th }}$ Eucarpia, 168.

Moses, M. and Umaharan, P. 2012. Genetic structure and phylogenetic relationships of Capsicum chinense. Journal of American Society of Horticultural Science. 137(4):250-262.

Naegele, R. P., Ashrafi, H., Hill, T. A., Chin-Wo, S. R., Deynze, A. E. V and Hausbeck, M. K., 2014. QTL Mapping of Fruit Rot Resistance to the Plant Pathogen Phytophthora capsici in a Recombinant Inbred Line Capsicum annuum Population. Phytopathology. 104(5): 479-483.
Naresh, P., Reddy, M.K., Reddy, P.H.C., Reddy, K.M. 2016. Screening chilli (Capsicum spp.) germplasm against Cucumber mosaic virus and Chilli veinal mottle virus and inheritance of resistance. Eur. J. Plant Pathol. 146:451-464cess 146(3): 451-464.

Nayak, S., Naik, P.K., Acharya, L., Mukherjee, A.K., Panda, P.C. and Das, P. 2005. Assessment of Genetic Diversity among 16 Promising Cultivars of Ginger Using Cytological and Molecular Markers. Z. Naturforsch Journal of Biosciences. 60 (56):485-492.

NHB, National Horticulture Board 2017. http://nhb.gov.in.

Ogundiwin EA, Berke TF, Massoudi M, Black LL, Huestis G, Choi D, Lee S, Prince JP (2005)

Construction of 2 intra-specific linkage maps and identification of resistance QTLs for

Phytophthora capsici root-rot and foliarblight diseases of pepper (Capsicum annuum

L.). Genome 48: 698-711.

Ozkaynak,E., Devran,Z., Kahveci, E., Doganlar, S., Baskoylu, B., Dogan, F., Isleyen, M., Yukse, A. and Yuksel, M. 2014. Pyramiding multiple genes for resistance to PVY, TSWV and PMMoV in pepper using molecular markers. Europ. J. Hort. Sci., 79 (4)S: 233-239.

Paterson, A.H. 1996. Making genetic maps. In: Paterson, A.H. (Ed.), Genome mapping in plants, Academic press, Austin, Texas 2329.

Patwardhan, A., Ray, S. and Roy, A. 2014. Molecular markers in phylogenetic studiesA review. J Phylogen Evolution Biol., 2:2. http://dx.doi.org/10.4172/2329-9002.10001 31.

Pena-Ortega, M. G., Rodríguez-Pérez, J. E., Martínez- Solís, J., 2013. Exploration of genetic variability of 'Mirasol' chili (Capsicum annum L.) accessions through ISSR Markers. Atiner Conference Paper Series No: AGR2013-0765. 1-14.

Perry, L., Dickau, R., Zarrillo, S., Holst, I., Pearsall, D.M., Piperno, D.R., Berman, M.J., Cooke, R.G., Rademaker, K., Ranere, A.J., Raymond, J.S., Sandweiss, D.H., 
Scaramelli, F., Tarble, K. and Zeidler, J.A.2007. Starch fossils and the domestication and dispersal of chili peppers (Capsicum spp. L.) in the Americas. Science doi:10.1126/science.1136914.

Pickersgill, B. 1997. Genetic resources and breeding of Capsicum spp. Euphytica 96:129-133.

Prince, J.P., Pochard, E. and Tanksley, S.D. 1993. Construction of molecular linkage map of pepper and a comparison of synteny with tomato. Genome 36: 404-417.

Rana. M., Sharma, R., Sharma, P., Bhardwaj, S.V. and Sharma, M., 2014. Estimation of Genetic Diversity in Capsicum annuum L. Germplasm Using PCR-Based Molecular Markers. Natl. Acad. Sci. Lett., 37(3):295301.

Rao, G.U., Ben-Chaim, A., Borovsky, Y and Paran, I.2003. Mapping of yield-related QTLs in pepper in an interspecific cross of Capsicum annuum and C. frutescens. Theor. Appl. Genet.106:1457-1466.

Romer, P., Jordan, T. and Lahaye, T., 2010. Identification and application of a DNAbased marker that is diagnostic for the pepper (Capsicum annuum) bacterial spot resistance gene Bs3. Plant Breeding, 129: $737-740$.

Romero-Da Cruz, M.V., Martins, E.R.F., Urdampilleta, J.D. and Moscone, E.A., 2017. Cytogenetic markers for the characterization of Capsicum annuum L. Cultivars. Plant Biosystems. 151(1): 84-91.

Salamon, P., Mityko, J., Kalo, P. and Szabo, Z., 2016. Symptoms caused by Tomato spotted wilt virus (TSWV) in pepper (Capsicum spp.) and marker assisted selection of TSWV resistant pepper lines for hybrid constructions. 69-75.

Sanatombi, K., Sen-Mandi, S. and Sharma, G.J. 2010. DNA profiling of Capsicum landraces of Manipur. Scientia Horticulturae 124: 405-408

Semagn, K. Bjornstad, A. and Ndjiondjop, M.N. 2006. Progress and prospects of marker assisted backcrossing as a tool in crop breeding programs. African Journal of Biotechnology. 5: 2588-2603.

Sergio, L. and Barcacciam, G. 2005. Molecular markers based analysis for crop germplasm preservation. The role of biotechnology for the characterization and conservation of crop, forestry, animal and fishery genetic resources. International Workshop, Turin, Italy, 5-7 March 2005.pp.1-12.

Silvar, C., Garcés-Claver, A., Mallor, C., Pomar, F., Rocha, F. AND Barata, A.M., 2016. Tracing back the history of pepper (Capsicum annuum L.) in the Iberian Peninsula. Proceed. XVI ${ }^{\text {th }}$ Eucarpia. 446450.

Singh, B.D. and Singh, A.K., 2015. IN: MarkerAssisted Plant Breeding: Principles and Practices. Springer publications, 1-512.

Struss,D., Mahasuk, P., Cline, E., Onmanee, N. and Mongkolporn,O. 2016. Mapping of QTLs conferring to Anthracnose resistance in chili pepper by SNP markers. agbio2017.com/wpcontent/uploads/2016/10/Abstract-DarushStruss.

Sugita, T., Kinoshita, T., Kawano, T., Yuji, K., Yamaguchi, K., Nagat, R., Shimizu, A., Chen, L., Kawasaki, S. and Todoroki, A.2005. Rapid construction of a linkage map using high-efficiency genome scanning/AFLP and RAPD, based on an intra-specific, doubled-haploid population of Capsicum annuum. Breeding Science. 55: 287-295.

Suwor, P., Sanitchon, J., Thummabenjapone, P., Kumar,S. and Techawongstien S., 2017. Inheritance analysis of anthracnose redsistance and marker assisted selection in introgression population of chilli (Capsicum annuum L.,). Scientia Horticulturae, 220: 20-26.

Sy, O., Steiner, R., and Bosland, P. W. 2008. Recombinant inbred line differential identifies race-specific resistance to Phytophthora root rot in Capsicum annuum. Phytopathology 98:867-870.

Tanaka, Y., Muraga, Y., Fukuta, S., Goto, T., Yoshida, Y. AND Yasuba, K., 2016. Multiple mutated putative aminotransferase alleles contribute to low pungency and capsinoid biosynthesis in Capsicum chinense. Proceed. XVI $I^{\text {th }}$ Eucarpia, 247.

Tanaka, Y., Yoneda, H., Hosokawa, M., Miwa, T. and Yazawa, S., 2014. Application of 
marker-assisted selection in breeding of a new fresh pepper cultivar (Capsicum annuum) containing capsinoids, lowpungent capsaicinoid analogs. Scientia Horticulturae, 165: 242-245.

Taranto, F., D’Agostino, N., Greco, B., Cardi, T. and Tripodi, P. 2016. Genome-wide SNP discovery and population structure analysis in pepper (Capsicum annuum) using Genotyping by sequencing. BMC Genomics. 17: 943.

Thabuis, A., Palloix, A., Servin, B., Daubèze, A.M., Signoret, P., Hospital, F. and Lefebvre, V. 2004. Marker-assisted introgression of 4 Phytophthora capsici resistance QTL alleles into a bell pepper line: validation of additive and epistatic effects. Molecular Breeding. 14: 9-20.

Thul, S.T., Darokar, M.P., Shasany, A.K. and Khanuja, S.P.S. 2012. Molecular profiling for genetic variability in Capsicum species based on ISSR and RAPD markers. Mol Biotechnol., 51: 137-147. DOI 10.1007/s12033-011-9446-y

Toledo-Aguilar,R., López-Sánchez, H., Santacruz-Varela1,A., $\quad$ ValadezMoctezuma,E., López,P.A., AguilarRincón, V.H., González-Hernández, V.A. and Vaquera-Huerta, H., 2016. Characterization of genetic diversity of native 'Ancho' chili populations of Mexico using microsatellite markers Chilean J.Agric. Res., 76(1): 18-26.

Toth, Z., Szabo, Z., Földi, T., Szabadi, N., Hajnik, L., Jeney, A., Kiss, G. B. AND Kalo, P.,2016. Genetic mapping and identification of the Mel gene conferring resistance to root-knot nematodes in pepper (Capsicum annuum L.). Proceed. XVI $I^{\text {th }}$ Eucarpi. 542545.

Truong, H. T. H., Kim, K. T., Kim, D. W., Kim,
S., Chae, Y. Park, J. H., Oh, D. G. and Cho, M. C., 2012. Identification of isolatespecific resistance QTLs to phytophthora root rot using an intra-specific recombinant inbred line population of pepper (Capsicum annuum). Plant Pathology (2012) 61, 4856.

Usman, M.G., Rafii, M.Y., Martini, M.Y., Yusuff, O. A., Ismail, M.R. and Miah, G., 2017. Introgression of heat shock protein (Hsp70 and sHsp) genes into the Malaysian elite chilli variety Kulai (Capsicum annuum L.) through the application of marker-assisted backcrossing (MAB). Cell Stress and Chaperones (pp.1-12). https://doi.org/10.1007/s12192-017-0836-3.

Venkatesh, J., An, J., Kang, W., Jahn,M. and Kang, B.C.H., 2017. Fine Mapping of the Dominant Potyvirus Resistance Gene Pvr7 Reveals a Relationship with Pvr4 in Capsicum annuum. Phytopathology, Volume 0, Number ja https://doi.org/10.10 94/PHYTO-07-17-0231-R.

Wahyuni, Y., Ballester, A. R., Sudarmonowati, E., Bino, R.J. and Bovy, A.G. 2013. Secondary metabolites of Capsicum species and their importance in the human diet. Journal of Natural Products. 76(4): 783-93.

Xu, X., Zeng, L., Li, Y. and Wang, H. 2014. Inheritance of resistance to Phythophtora capsici in Capsicum annuum and analysis of relative srap markers. Journal of Chemical and Pharmaceutical Research. 6(6):1967-1972.

Yames, S.C., Ashrafi, H., Reyes-Chim-Wo, S., Hill, T. A., Stoffel, K.M. and Deynze, A.V. 2013. Identification of QTLs for capsaicinoids, fruit quality and plant architecture-related traits in an interspecific Capsicum RIL population. Genome. 56(1):61-74.

\section{How to cite this article:}

Bhaganna Haralayya and Asha, I.S. 2017. Molecular Marker Application in Capsicum spp: A Supplement to Conventional Plant Breeding. Int.J.Curr.Microbiol.App.Sci. 6(11): 3840-3855. doi: https://doi.org/10.20546/ijcmas.2017.611.451 